Title: The Cultural Tastes of Bourgeois Pre-adolescents in France: Cultural Omnivorousness as a New Form of Cultural Capital

[The Cultural Tastes of Bourgeois Pre-adolescents in France: Cultural Omnivorousness as a New Form of Cultural Capital," Contemporary French Civilization, fall 2019, Volum]e 44, Issue 4.

Author: Scott Gunther, Wellesley College

\begin{abstract}
:
This is an ethnographic study of the reception of popular culture (music, films, and television) among bourgeois, Parisian children between the ages of 7 and 12. Pierre Bourdieu's idea of social distinction has been used as a model to describe the tastes of the French bourgeoisie since the 1970s, though some sociologists, such as Joël Zaffran and Marie-Laure Pouchadon, have argued that its usefulness in recent decades has waned. In this article, I argue that the notion of social distinction is just as useful now as it was in the $1970 \mathrm{~s}$, but that based on the tastes of these young, bourgeois informants, the criteria for what constitutes cultural capital, an essential ingredient for social distinction, have changed. This study supports the notion that the distinction between high and low culture, which used to be central to achieving social distinction, has been supplanted by a new criterion for social distinction that relies on "cultural omnivorousness." These children's parents already exhibited some signs of valuing culturally omnivorous tastes and were the first generation to do so. The fact that an appreciation for cultural omnivorousness has been transmitted from bourgeois parents to these pre-adolescent children is a sign that this means of achieving social distinction has gone from a probationary, exploratory phase to a more stable and lasting one.

Ceci est une étude ethnographique de la réception de la culture populaire (musique, cinéma, et télévision) chez des enfants bourgeois parisiens âgés de 7 à 12 ans. Depuis les années 1970, le concept de Pierre Bourdieu de la distinction sociale sert à décrire les goûts de la bourgeoisie française, bien que certains sociologues, tels que Joël Zaffran et Marie-Laure Pouchadon prétendent que son utilité a diminué au cours des dernières décennies. Dans cet article, je soutiens l'idée que la notion de la distinction sociale est aussi utile maintenant qu'elle n'a été dans les années 1970, mais les goûts de ces jeunes informateurs bourgeois indiquent que les critères qui déterminent ce qui constitue le capital culturel, un ingrédient essential de la distinction sociale, ont changé. Cette étude soutient la notion que la distinction entre la culture avec un grand $\mathrm{C}$ et la culture populaire, qui autrefois était centrale à l'acquisition de la distinction sociale, a été supplantée par un nouveau critère pour la distinction sociale qui dépend d'une "consomption culturelle omnivore." Les parents de ces enfants ont déjà présenté des signes de valoriser des goûts culturellement omnivores et ont été la première génération à le faire. Le fait que l'appréciation d'une consomption culturelle omnivore a été transmise des parents bourgeois à ces enfants pré-adolescents est un signe que ce moyen d'acquérir de la distinction sociale est passé d'une phase exploratoire potentiellement temporaire à une phase plus stable et durable.
\end{abstract}




\section{The Cultural Tastes of Bourgeois Pre-adolescents in France: Cultural Ominvorousness as a New Form of Cultural Capital}

Pierre Bourdieu's idea of social distinction has been used as a model to describe the tastes of the French bourgeoisie since the 1970s, though some sociologists, such as Joël Zaffran and MarieLaure Pouchadon, have argued that its usefulness in recent decades has waned (Pouchadon and Zaffran). In this article, I argue that the notion of social distinction is just as useful now as it was in the 1970s, but that the criteria for what constitutes cultural capital, an essential ingredient for social distinction, have changed.

This is an ethnographic study of the reception of popular culture (music, films, books, television, and video games) among bourgeois, French children between the ages of 7 and 12, whose parents all have high levels of cultural capital (measured by levels of education). ${ }^{1}$ Almost all of them have high levels of economic capital as well. They are what might be called "bourgeoisbohemians" or "Bobos," a category that entered the French vernacular in the early 2000 s. $^{2}$ While Bobos are defined as both bourgeois and bohemian, the bourgeois component of the definition matters more, to the extent that Bobos should be understood simply as new form of bourgeois (Gunther). Bobo tastes, however, are not the same as their bourgeois predecessors. For one thing, they do not live in the traditionally bourgeois neighborhoods of western Paris, but have opted instead for the more multi-ethnic, working-class - although quickly gentrifying - neighborhoods to the east. In addition, their political views are solidly on the left, especially with respect to ecological and social issues, such as same-sex marriage. Also, rather than pursuing traditionally bourgeois careers in fields like medicine, law, or business, Bobos tend to have jobs in creative, artistic, educational, or high-tech sectors. What they share with the traditional bourgeoisie is a 
preoccupation with acquiring various forms of capital, including economic, social, and cultural capital, and passing them on to future generations.

For Pierre Bourdieu, to be bourgeois requires participation in "a multidimensional status game in which people draw on three different types of resources [what he terms economic, cultural, and social capital] to compete for status [what he terms 'symbolic capital']. Distinct from economic capital (financial resources) and social capital (relationships, organizational affiliations, networks), cultural capital consists of a set of socially rare and distinctive tastes, skills, knowledge, and practices" (Holt 3). For Bobos, cultural capital matters more than economic capital. Sociologist Sophie Corbillé explained in her study of Bobos that they make up "a social group that occupies a relatively high position in the social hierarchy, endowed with some economic capital, although this can vary, along with strong social and cultural capital linked to family origin, educational pursuits and professional activities" (Corbillé 96, emphasis added). Similarly, in Laure Watrin and Thomas Legrand's study, La République bobo, they define Bobos as "people whose cultural capital (high) carries more weight than their economic capital (varied) in determining where to live and which values they consider positive or negative" (Watrin and Legrand 33, emphasis added).

It is clear that the informants for this article should not be seen as typical, French - or even as typical, Parisian - children (indeed, several parents felt the need to point this out to me). Almost all these children have traveled extensively outside France, have easy access to foreign media sources through services like Netflix and cable television, live in families with a variety of electronic media devices including e-readers, tablet computers, smartphones, and screens connected to cable channels and digital video recorders. They all demonstrated high levels of technological sophistication, including familiarity with a wide range of electronic devices and 
knowledge of how to find less main-stream media sources on the internet, along with high levels of cultural sophistication, including for example, knowledge of what sorts of music or films are associated with "high culture."

Some work has already been done on the reception of globalized popular culture by teens or preteens in other countries, but this work has focused primarily on non-Western countries, including Ecuador, Vietnam and Nigeria. ${ }^{3}$ These studies have relied on notions of cultural imperialism, which emphasizes the power of Western culture and efforts to resist it in non-Western cultures, or alternatively on hybridity, which represents the process not as a one-way influence of the dominant Western center on the non-Western periphery, but as one where local and foreign cultures are blended resulting in a cultural identity that preserves local specificities. France represents an entirely different cultural environment. It has a strong sense of national identity and has itself been in the position of exporting its culture to other places, arguably more than any other Western country besides the United States. In addition, defenders of French culture consider it to be on par with, if not superior to, American culture, so the power dynamics of the French situation are entirely different from those in non-Western countries. Unlike the preadolescents from the Ecuadorian, Vietnamese and Nigerian studies, who were keenly aware of their country's hierarchical position relative to other, primarily Western, countries, the young, French, bourgeois informants of this study were not concerned about France's position among world cultures. They were, however, mindful of their own social position within France.

Beginning with the generation of these children's parents, the distinction between high and low culture, which used to be central to achieving social distinction for earlier bourgeois generations in France, was supplanted by a new criterion for social distinction that relies on "cultural omnivorousness." Unlike their parents, however, who broke with the criteria used for social 
distinction by earlier generations, these children have imitated the culturally omnivorous tastes of their parents, thereby confirming that cultural omnivorousness has now become a means of reproducing class distinction.

\section{Methodology}

I conducted interviews with 25 pre-adolescent children between the ages of 7 and 12 in the summer of 2017. ${ }^{4}$ The children knew that I was American, which may have influenced their responses. They may, for example, have spent more time explaining French cultural phenomena to me than they would have to a native-French interviewer or felt less comfortable asserting negative opinions of US popular culture.

I met with the informants in small groups (two to five children at a time) for approximately 45 minutes. Most of these interviews took place in the homes of one of the children interviewed. Two of the meetings were held at the Médiatheque Françoise Sagan in Paris and one was held in a café. I made audio recordings of these conversations and transcribed them. The interviews were conducted in French and translations of the informants' statements are my own. I began by asking them open-ended questions about their media practices: What kinds of media do they consume? What do they like and dislike? Why? I asked parents not to be present or to participate in these discussions. Afterward, I would spend a few minutes talking with the parents to get information about their educational levels and professional paths, which gave me a general sense of their levels of cultural and economic capital.

I found informants by contacting people who participated in a study I conducted in 2013 and 2014 on Parisian "Bobos" who have children of that age group and agreed to let me meet with them (Gunther). I asked these parents to put me in contact with other parents, a method 
commonly referred to as "snowball sampling," which has both disadvantages (the sample may not be representative since it lacks randomness) and advantages (it allows researchers to locate members of populations where there might not be any lists or other sources for finding them). Consequently, almost all the informants (21 out of 25$)$ live in the same neighborhood, the $10^{\text {th }}$ arrondissement of Paris, or what can be considered the heart of "Boboland." The four children who do not live in the $10^{\text {th }}$ arrondissement nevertheless have parents with ties to parents in this neighborhood, since they were referred to me by friends of theirs living there. Though the parents of these four children lack the geographic criterion for what constitutes a Bobo, they satisfy the other criteria, including having careers in creative or high-tech sectors, left-leaning political values, high levels of education, and an openness to foreign cultures.

\section{Cultural omnivorousness as a new form of cultural capital}

Joël Zaffran and Marie-Laure Pouchadon contend that Bourdieu's notion of social distinction was a useful means of analyzing adolescent tastes back in the 1960s and 70s, but argue that today, with the erosion of the distinction between high and low culture, the paradigm of social distinction is of less explanative value (Pouchadon and Zaffran 171-172). ${ }^{5}$ My study, however, stems from the work of other sociologists, inspired by the ideas of Richard Peterson, who have argued otherwise, claiming instead that the distinction between high and low culture has been merely replaced with a new criterion for social distinction that relies on "cultural omnivorousness" and have found a correlation between omnivorous cultural tastes and high social status, mostly in the form of advanced education. ${ }^{6}$

For Peterson, omnivorous taste "does not signify that the omnivore likes everything indiscriminately. Rather, it signifies an openness to appreciating everything. In this sense, it is antithetical to snobbishness, which is based fundamentally on rigid rules of exclusion...such as: 
'It is de rigueur to like opera, and country music is an anathema to be shunned"' (Peterson and Kern 904). In this way, it is not genres themselves that are not hierarchized, but rather the cultural products that exist within each genre. In addition, the ethnocentrism that frequently accompanies univorous cultural taste is replaced with cultural relativism, so that each cultural product is not evaluated simply according to whether it is part of the canon of high culture, but in its own context.

Cultural capital, like any form of capital for that matter, cannot be easy to acquire, or else it would lose its value, and so, if being a discerning cultural omnivore contributes to cultural capital, it cannot be too easy to become one. It requires deep knowledge of hierarchies within all genres as opposed to the traditional bourgeois model, which consisted of acquiring knowledge primarily about cultural products that belonged to high-brow genres. It is consequently not surprising that the distinction between univorous and omnivorous tastes is correlated with social class, such that "the probability of being a univore declines steadily as level of status and also of education increase. On the other hand, the probability of...being a true omnivore [is] positively related to status and education" (Chan and Goldthorpe 13).

The univore/omnivore distinction, which originated in the Anglo-American context, has also been observed in the French context. In their study of French musical tastes across social groups, Hervé Glévareca and Michel Pinet concluded that "the high status groups have become more heterogeneous...in their musical choices and perhaps also more broadly in their cultural choices... We would argue that this model can also apply to literature, television and comic books because the heterogeneity of legitimacy orders also applies to books (i.e. detective novels for example are legitimised), television ("quality" television series) and comic books (comics of Japanese origin, manga), etc. One key point of [this study is that] the internal hierarchy and 
cultural judgments are located 'in' genre and no longer 'between' genres as argued by Bourdieu in the Distinction model" (Glévarec and Pinet 81). Olivier Donnat's study of French tastes came to similar conclusions, using the term "cultural eclecticism" instead of omnivore: "The world of the hip (branché) people, which lies at the intersection of the worlds of the classical and the modern, is made up of a dominant minority of skilled consumers of cultural offerings... The main organizer of their tastes is eclecticism, which is the ability to make associations across...literary, musical, and performance genres, which seem disconnected or even irreconcilable. This ability to separate the wheat from the chaff, regardless of the status of the... genres in question requires as strong of a familiarity with classical music as with other forms of modern expression, and requires the possession of many advantages in terms of cultural capital, including the availability and proximity of cultural offerings. To be a part of this world is largely the privilege of middleaged, unmarried people with advanced degrees living in large cities, especially Paris" (Donnat 91). Others studies from Guy Bellavance, Myrtille Valex, Michel Ratté, and Philippe Coulangeon have come to similar conclusions in the French context.(Bellavance et al.; Coulangeon)

This article, which looks at the tastes of pre-adolescents, builds on these studies that found cultural omnivorousness to be a new form of cultural capital in bourgeois adults. It shows that this shift in the definition of what constitutes cultural capital has now been transmitted to a younger generation. By looking at the case of pre-adolescents as opposed to adults, this study tells us that the social value associated with cultural omnivorousness is not going away anytime soon. If anything, given the increase in options for cultural consumption (due primarily to technological changes, but also to increased ethnic diversity in France) it is likely to grow even stronger. These children's parents were the first bourgeois generation to value culturally 
omnivorous tastes. This study shows that the appreciation for cultural omnivorousness has now been transmitted from one bourgeois generation to another and has thus become a means of reproducing class distinction.

\section{Findings}

The tastes of these children reflected tensions of three different types: First, their tastes showed high levels of cosmopolitan sophistication at times, while at others, exposed ignorance of the world beyond France; second, their tastes were often an imitation of those of their parents, though sometimes they indicated the children's efforts to distinguish themselves from their parents; and finally, their tastes were shaped by both the desire to increase social distinction and the pressure for social conformity, which is relatively strong at their age. All three of these tensions are related to their position as somewhere between childhood and adulthood and are useful in thinking about why the informants' tastes both resemble and differ from the tastes that adults in their social milieu are expected to have. They also all demonstrate the extent to which cultural omnivorousness has become an important form of cultural capital in their social environment.

\section{Cosmopolitan sophistication vs. ignorance of foreign places}

One prominent feature of these children's tastes was the extent to which they consumed cultural products from places other than France and the lack of a hierarchy of cultural products based on their countries of origin. However, the fact that they consume media from a range of countries may not be sufficient to label their tastes cosmopolitan. As Vincenzo Cicchelli and Sylvie Octobre explain, it is important "to distinguish clearly between consumption patterns and the intentionality behind them: one can consume numerous foreign products without ever 
considering the alterity, one can also consume few foreign products in a particular cultural sector and develop a strong sense of curiosity. Intention is at the core of a cosmopolitan attitude" (Cicchelli and Octobre 49). In this study, the children did not consume media from different countries indiscriminately, but chose media from around the globe according to the media that each place was known for. This is similar to the conclusion reached by a 2016 study from the Ministry of Culture and Communication of young people between the ages of 18 and 26, for whom "Hollywood produces blockbusters, science fiction movies, and action movies, Bollywood is known for its singing romantic comedies, Asian cinema is associated with martial arts films and animated films. In the same way, certain television series are 'American' because of the jumpiness of their editing and the rhythm of their scripts, others are 'British' through their humor and historical precision; yet others are 'French' by their focus on family life and emotions. For animated films, the label 'Franco-Belgian,' 'manga,' and 'comics' refer to three distinct esthetics linked to specific cultural origins. And finally, music is 'American' if it is rock, rap, blue, or R\&B, 'British' if it is pop, and more recently, 'Korean' if it is K-pop - and lastly, 'French' if it is soft rock or vocal music (variétes)' (Cicchelli and Octobre 32).

One informant, Samuel (age 10), said he watches more foreign movies than French movies, because his mother has many Chinese and Indian films. Samuel explained that "my mom has three or four shelves of Chinese DVDs, about four shelves of Indian movies, and only two shelves of French movies." He went on to say that he likes Chinese movies but not Indian movies, because "the Chinese movies are well made, but the Indian films are just a bunch of people dancing around."

Chloé [age 10] was also open to media from other places and made choices based on a country's reputation for good music: "Every time a new pop song comes out, I give it chance, regardless of 
the language. What matters is the rhythm and some countries just have better rhythms" [with this, several other children spontaneously started singing "Youpala, youpala...," a song from Zaak Tanjawi, who is of Moroccan origin].

Others made similar comments including:

Interviewer: "Does the fact that the [amusement park] Park Astérix is based on a French character while Disney is American make a difference?"

Adam [age 12]: "The difference is that Disney just knows how to make better rides."

Adam [age 12]: "Yeah, I used to listen to a lot of Eminem, but now I listen to lots of different things, techno, rap...Good rap is French or American, but the problem with French rap is that I understand the words and can tell it's vulgar, sometimes even very vulgar, which my parents don't like."

Chloé [age 10]: "I watch series in Spanish like Chica Vampiro and Soy Luna, because they're better than the French shows."

It is perhaps less surprising to see the ease with which they move between cultural products from France and elsewhere when one considers how extensively they have traveled. All of them had travelled to multiple countries outside of France, and about half of them had gone outside of Europe. Five of them had been to the United States (two of them for extended periods of time), four to places in Asia, and three to places in Africa. In their multi-ethnic neighborhood in Paris, they go to school with children from other countries and have access to restaurants and shops with cuisines from around the world. In discussing their favorite foods, they generally made little distinction between French foods and foods from other places. The most common foreign 
cuisines mentioned were Japanese, Chinese, Vietnamese, North African, and Indian. I was particularly struck by Théo's [age 9] level of sophistication in describing his favorite dish: "I love Tiep, it's an African dish. [My family and I] go to the market and we buy home-made Tiep. It's from Senegal. It's grouper, mixed with cooked cabbage. It's so good, I promise. It's a stew with fish, cooked cabbage, cassava, potatoes, carrots, and all that with sauce. Oh, and red rice!" Yet, despite their openness to other cultures, many informants demonstrated some ignorance of other cultures, as should be expected considering their age.

Quentin [age 9]: "I love Star Wars, Harry Potter, Jurassic Park.” Interviewer: "Are there any French films you like?" Quentin [age 9]: “I don’t even know of any French films. They're all American. Oh wait, there's Mary Poppins, that's French right?"
Alma [age 12]: "But over there [in the US] children wear uniforms to school." [Alma was one of several children to make this comment. My guess is that this is from images of school children in uniforms in Harry Potter books and films and their conflation of the United States and England.]

Ignorance of differences among foreign places would seem to undermine Vincenzo Cicchelli and Sylvie Octobre's idea that the desire to consume cultural products from a variety of places must be intentional in order for such consumption to be labeled "cosmopolitan." In this case, however, the informants' displays of ignorance were not common enough to challenge the overall intentionality of their cultural choices.

Cosmopolitan tastes have always contributed to cultural capital. To know what is good beyond France requires effort and this assures that such knowledge remains rare, an essential ingredient 
for cultural capital. However, this has traditionally not been the case for knowledge of US popular culture, which is omnipresent and easy to access, and hence has traditionally contributed little to one's cultural capital. Richard Kuisel has pointed out that in the decades following World War II, there was a strong correlation between social class and attitudes toward American popular media, such that "elites more than the average French men or women...harbored cultural anti-Americanism" (Kuisel, Seducing the French: The Dilemma of Americanization 34-35).

Consequently, one would expect my young bourgeois informants to be somewhat dismissive of American cultural products, but it turns out that there was no evidence of this being the case. Indeed, before conducting this study, my initial expectation was that it would enable me to analyze the sorts of distinctions French children make between French media and foreign, especially US, media. During my conversations with the children, I did not ask them explicitly to compare French and US media, but analyzed the transcripts later to look for subtle indications of a distinction between US and French media. In the end, this distinction was of little or no concern to them. Instead, as will be discussed below, other distinctions were more salient.

My informants' lack of distinction between American and French cultural products does fit with Kuisel's most recent study, however, where he notes that by the end of the $20^{\text {th }}$ century, the split between the French elite and the general public in attitudes toward American cultural products had disappeared:

With respect to American popular culture, conventional wisdom has held that elites have been less receptive than the public...[but] surveys do not corroborate this thesis for the fin de siècle. Or, at least, the two social groups seemed to agree if the question asked was simply, "In general what is your opinion of American popular culture such as music, television, and films?" Faced with a 
favorable/unfavorable binary, favorable answers were given by the public and elites at almost the same levels (52 percent and 49 percent, respectively) in 2000 (Kuisel, The French Way 346).

How then does one explain this change in attitudes toward US cultural products among French elites? The statements from these pre-teens offer some clues. The informants for this study consumed large amounts of foreign media, and it is true that they did not create hierarchies of cultural products based merely on the products' countries of origin. This does not mean, however, that they consumed indiscriminately. Instead in most cases, what mattered to them was not whether the cultural product came from a place that was perceived to be culturally sophisticated across the board, but whether it came from a place with a reputation for quality with respect to that specific cultural genre. This is a one important feature of cultural omnivorousness.

It is important to note that consumption of foreign media on its own is not inevitably perceived as cosmopolitan, nor does it necessarily contribute to cultural capital. I mentioned in the introduction to this article that these children should not be considered typical Parisian children, because of their technological sophistication and their access to foreign cultures. But there is another way in which they are not representative of the children that inhabit their neighborhood: though almost all of them live in the highly ethnically diverse $10^{\text {th }}$ arrondissement, all of their parents, with the exception of just two, were white, "Français de souche" (the two others were each in a bi-national couple with a French person). I deliberately chose classically "FrancoFrench" pseudonyms for them for this reason. Many non-Bobo children in their neighborhood have foreign parents, speak a language other than French at home, are deeply familiar with their parents' cultures, periodically visit their parents' countries of origin, and consume media from 
these countries, while at the same time, speaking French, learning about French culture and history, and consuming French media. Yet this kind of bi- (or often multi-) culturalism is not valued in the same way as the Bobo children's openness to foreign cultures.

This distinction is echoed in other studies of the value given to elite cosmopolitanism and the lack of value given to the multiculturalism of immigrant populations in Western countries. In her study of immigrants living in Berlin, Jude Bloomfield distinguishes between "weltoffen" ("cosmopolitan" or literally, "open to the world") and "multicultural." The former describes the image that Berlin's elite would like to project of their city as “an internationally open, high cultural metropolis," while the latter, which is associated with the day-to-day experience of the city's hundreds of thousands of foreign residents, is largely unacknowledged (Bloomfield 1). Ruth Mandel's study of the social position of Turks in Germany finds that "the stereotype that would isolate a mustached Turkish migrant slicing meat off his rotisserie in a kebab shop fails to recognize that an entire transnational world unfolds within these very boundaries." Not only does this person need to learn to speak German and to navigate German bureaucracy, but also to understand German cultural tastes well enough to develop a product that Germans actually want, as opposed to one that is based on an authentic Turkish recipe. She argues for "a more nuanced understanding of the immigrant population [that] might view Turkish Germans less as ghettoized victims than creative players whose skills may be transferred across boundaries-geographic, political, or cultural" (Mandel 312). In his study of the meaning of "cosmopolitanism" in the West, Craig Calhoun explains that the distinction between elite cosmopolitanism and common cultural diversity exists, because it serves as a means of preserving social inequality:

Cosmopolitanism — though not necessarily cosmopolitan democracy— is now largely the project of capitalism, and it flourishes in the top management of 
multinational corporations and even more in the consulting firms that serve them. Such cosmopolitanism often joins elites across national borders while ordinary people live in local communities. This is not simply because common folk are less sympathetic to diversity—a self- serving notion of elites...[A]dvocates of cosmopolitan democracy often offer a vision of political reform attractive to elites partly because it promises to find virtue without radical redistribution of wealth or power (Calhoun 890-893).

In a similar way to the studies mentioned above, the case of Bobo children in Paris is an illustration of how social distinction along ethnic lines is preserved by distinguishing between elite cosmopolitanism and the day-to-day multiculturalism of foreign children. The French context, however, is not the same as that of Germany. While the multiculturalism of immigrants in Germany might be merely unappreciated, in France it is decried. Under the French Republican model, assimilation is highly valued and multiculturalism is not. Immigrants to France must leave cultural differences at the border, lest they be accused of communautarisme. As a result, a child of North-African descent who consumes both French and North-African media is likely to serve as an example of a failure to assimilate, whereas an ethnically French child who does the same can be seen as open to the world.

\section{Imitating vs. distinguishing themselves from their parents}

While the cultural practices of parents may not entirely determine the content of children's cultural consumption, they are relatively strong predictors of the amount of media children will consume, such that the children of parents who consume relatively little cultural content from a particular medium are likely themselves to consume little content from that medium (1.5 more 
likely in the case of music and video games, 2.5 times more likely for reading, and 3 times more likely for television and internet use) (Octobre 211).

Children as inheritors of cultural taste can adopt one of three positions: they can reproduce the tastes of their parents with some adjustments to allow for individual appropriation (for example, developing an appreciation for the same genres of film without necessarily liking the same specific films); they can redirect the inherited tastes by maintaining the same intensity of consumption but for other cultural content (for example, by reading manga instead of graphic novels); or they can refuse the transmission of tastes (Octobre 212). Children's tastes often reflect a combination of these three positions, reproducing some tastes and redirecting or refusing others.

In this study, the informants' tastes showed signs of being inspired by those of their parents. While none of the informants said explicitly that they were copying their parents' tastes, their statements often acknowledged that they happened to share tastes with their parents or that they were on their way to having tastes similar to those of their parents.

Noah [age 7]: "I love films from the old days, because they're different. There are actors like you don't see any more, like Louis de Funès, Pierre Richard. Charlie Chapin movies too, I like those. Even if there aren't words, they're funny... I love movies that are in black and white, and there are no words, they express themselves without using words, just by moving. They're very theatrical in these films...I learned about these movies from my parents. They like them too.” 
Clément [age 9]: "When I grow up, I'll watch movies with more complicated words. I think I'll watch movies in English where there won't even be subtitles like my parents do.”

One feature of Bobo tastes is the rejection of ostentatious displays of wealth. In my study of Bobos, I found that "the expression of Bobo taste is discreet in all forms of consumption, but this is particularly true with fashion, where codes are often decipherable only to other Bobos" (Gunther 117). This was reflected in the statements from the few informants who talked about clothing. Violette [age 11] said, for example, that "I like fashion, but I don't want to have a brand displayed on my clothes. Well, except for sneakers, there I want to have a brand showing something like Nike or Adidas."

Another feature of Bobo taste is an appreciation for the ethnic diversity of contemporary France. Bobo parents are different from other bourgeois parents, because they have chosen to leave traditionally bourgeois neighborhoods in western Paris for less expensive neighborhoods in the northeastern part of the city. This migration of young bourgeois adults has been accompanied by an increase in the social value associated with living in an economically and ethnically diverse neighborhood. In her study of the gentrification of northeastern Paris, Anne Clerval explains:

Because it is cosmopolitan and socially varied, the [gentrified] neighborhood does not represent a village, but a miniature world city, allowing the gentrifiers to link symbolically the nearby social diversity with their openness to the world. By doing this, the local space of the neighborhood becomes symbolic and material capital for the gentrifiers. It is part of a strategy of social distinction.... Valuing social diversity allows them above all to make a virtue out of necessity, transforming real estate limitations into deliberate choices. It is also an 
opportunity for conspicuous expression of high moral values, such as openness of mind and tolerance (Clerval 168-170).

The appreciation of ethnic diversity was especially apparent in the significant number of informants (12 out of 25) whose favorite music genre is banlieue music, either in the form of hip hop or rap. Though these musical styles originated in the United States, "French banlieue music very early showed characteristics quite different than those of American hip-hop, most notably, the French form quickly became used as a musical way of affirming the multiethnic composition of France's population and of articulating a vision of identity that both recognizes and valorizes diversity" (Oscherwitz 45).

Yet, despite the similarities between the parents' and children's tastes, there were a couple of differences. One difference has to do with the fact that these children's parents, who moved from the traditional bourgeois neighborhoods in western Paris to the working-class neighborhoods in the northeast, saw themselves as pioneers, while for most of the children in this study, Boboland is where they were born and all they have known. These children's parents were able to reduce the bourgeois guilt associated with the high economic inequality of these rapidly gentrifying neighborhoods by thinking of themselves as cultural explorers living among "the people," in ethnically diverse neighborhoods, and as left-leaning progressives willing to break with the political values of the traditional bourgeoisie. The children, however, cannot benefit from same kind of smug satisfaction that comes from being cultural pioneers like their parents, because their appreciation of ethnic diversity and their espousal of progressive political values did not develop in opposition to their parents' values but were passed on from them. 
The second difference is the relatively small importance that these children grant to whether a cultural product came from France or somewhere else, and in particular the United States, compared to their parents.

Jane [age 10]: "My parents don't like American series because of the laugh tracks."

Alma [age 12]: "Yeah, my parents say they're worthless. They always tell me, 'Stop watching that American crap!'”

Jane [age 10]: "Yeah, they think they look fake, since they don't have 'real' actors."

Clément [age 9]: "Disney characters are just stupid. They're all like 'Hi, I'm Mickey’ [said with a silly, childish voice]."

Alma [age 12]: "Yeah, well even if they have stupid characters, the rides in Disneyland are good."

Jane [age 10]: "Yeah, my parents don't like Disney."

Interviewer: "Do you know why?"

Jane [age 10]: "No, I don't know. They just say it’s worthless (in French, “nul”)."

Clément [age 9]: "Yeah, my parents don’t like Disney either. They say, 'Oh no, let's not go to Disneyland. It's so stupid (in French, "nul"). I'm not sure why they don't like it."

One way of interpreting these quotations is that the informants' generation is less culturally antiAmerican than their parents' generation. However, this interpretation would oversimplify their parents' attitudes toward US culture. I discovered in my brief conversations with the informants' 
parents, that they do not dismiss US cultural products across the board. The shift from a hierarchization of foreign cultures to hierarchizations within the cultural offerings of each country described in the previous section was also evidenced in the tastes of the informants' parents. Similarly, the parents did not create hierarchies of genres, where for example, all classical music would be superior to all popular music, but instead, recognized that there were both good and bad cultural offerings within each genre. Virtually all the parents who talked to me about US television expressed contempt for traditional American sitcoms shown dubbed on French airwaves, while showing an appreciation for American series available on Netflix or cable TV, such as House of Cards, Breaking Bad, or Game of Thrones, and the children seem to be learning the distinction between good television options and bad ones from their parents. For example, Alma [age 12] explained that “my parents don't want me to watch just anything. I mean, they say that I can only watch series where each episode builds on the last one." Almost all the informants' parents entered adolescence in the 1980s, a decade that might be seen as a turning point in this regard. One sign of a cultural shift was the French Ministry of Culture's decision in the early 1980s to begin "developing a sympathetic public discourse on youth culture generally and music particularly" (Looseley 261). The Ministry's intent was not to value all youth culture, but to recognize that within the traditionally low-brow category of "youth culture," one could find cultural products of value. These parents were the first bourgeois generation to recognize the potential value of cultural products across genres and to see cultural omnivorousness as a means for acquiring cultural capital.

Another interpretation is that the informants are mid-way in the process of acquiring the tastes they should have as adults in their social milieu. Media scholars have a term for the distance between the desirable (that which one should want in one's social milieu) and the desired (that 
which one actually wants): they call it the "value paradox" (Mooij 78). These informants all had parents with high levels of education (high cultural capital), and in that environment, children are expected to learn which types of cultural consumption carry the highest levels of cultural capital and represent the desirable, though the unfiltered desired from childhood continues to have an influence on them. They are beginning to learn that it is not a question of whether a particular genre, such as American television, should or should not represent the desirable, but rather, that within the genre, there are both desirable and undesirable options.

\section{Social distinction vs. social conformity}

The most significant features of these children's tastes was the lack of evidence of a hierarchy of genres. The near disappearance of hierarchal understanding of genres does not, however, necessarily lead to a reduction in the desire for social distinction. Instead, social distinction relies, at least in part, on a recent form of cultural capital, which is obtained through openness to both foreign cultural products and to cultural products from across a wide array of genres. In her study of cultural consumption patterns of adults in Quebec, the sociologist Michèle Ollivier observed something similar:

"[Humanist openness] is the ability to finely discriminate and choose among a wide range of cultural options, from the most commonly available products of popular culture to much more exclusive forms of high and folk cultures of the world. The celebration of extensive and voluntary mobility between cultural forms, which is at the core of humanist openness, is most readily available to people who possess not only large quantities, but also the right kind of symbolic and material resources. Humanist openness is often presented as a quality naturally attached to deserving individuals, glossing over the fact that the 
resources necessary for its appropriation are not equally distributed. Openness to diversity thus becomes a new form of cultural capital, in the Bourdieusian sense of cultural resources that are widely considered desirable but not equally available to all" (Ollivier 142).

For media forms such as music, films, and books, my informants consumed a wide range of genres, including many genres that have traditionally not been associated with high culture (pop music, blockbuster films, comic books). It would be incorrect, however, to interpret this as a lack of appreciation for the value of accumulating cultural capital. Rather than imagining one genre as superior to another, these informants created hierarchies of offerings within each genre. In other words, they did not like all comic books, for example, but recognized a hierarchy within the medium and gravitated toward those comic books associated with higher levels of social prestige.

For example, Samuel (age 10) demonstrated a clear desire to distinguish himself from his peers when he said that "most kids only know the big manga classics, but I have dug much deeper to find the less known manga." He said that he does not share tastes with ordinary French kids at school, because he knows "a lot more about manga than they do" and consequently, has not "found many kids to share manga with." Samuel also prefers watching manga with subtitles, because "the Japanese voices are much better." He has found special websites where he can watch manga in Japanese and he made a point of telling the interviewer that these sites are not easy to find. He also said that he understands some Japanese words now, which he has learned just from watching manga.

The social prestige associated with a particular cultural product could come from an evaluation of its quality, but it can also come from its rarity. The informants' statements indicated that there 
was value in having access to a product that was out of the ordinary. One informant, Maxime [age 10], said that he could not wait for new Legend of Zelda [video game] to come out, and that he would be able to get it earlier than other French children, because he is going to get the Japanese version. He said he did not mind if the game is in Japanese, what mattered was that he would be able to get it before everyone else. In some cases, the cultural product was not actually rare, but the informant perceived it to be rare. For example, Théo [age 9] explained that “sometimes I like to listen to Sheila, a French singer. She's not very well known." The truth is that she used to be very well known in the 1960s, 70s and 80s, though what matters is that he believes she is unknown, at least among his peers.

When an informant from the same interview group liked the same thing as someone else, this was frequently met with an expression of displeasure by the person who first mentioned it. It was a recognition of the value of developing unique, personal tastes. It was surprising that this reaction could even occur with widely consumed cultural products:

Jennie [age 9]: "The thing I really like is Harry Potter." Chloé [age 10]: "Yes, I like Harry Potter too." Jennie [age 9]: “Copycat!”

The hierarchization of genres was not entirely absent, however. There was evidence, for example, that reading books carried more cultural capital than watching television. Five out of the twenty-five informants made a point of saying that they did not have a television in their house, but watched series from services like Netflix on screens connected to computers instead. There was absolutely no shame associated with not owning a television, in fact, it seemed that they were saying this with pride, because they recognized that in their social environment not having a television had nothing to do with being able to afford one, but represented a recognition 
that ordinary television programming was something available to almost anyone, and hence, provided little opportunity for social distinction. On the other hand, when they spoke about reading, they recognized that this was a socially valued activity and something that could distinguish them from other children:

Gabriel [age 9]: “As for me, I read graphic novels, but my friends, they don’t like to read."

Adam [age 12]: “For me, it's mostly manga or novels. I read more than my friends at school, because I have an e-reader, it's a Kindle. And I buy lots of novels and I read them."

Many of the informants also seemed to understand that subtitles could contribute to their social distinction more than dubbing could, and though most of them recognized the additional effort subtitles require, they overwhelmingly preferred them. Maxime [age 10] said that the "words are much better" when there are subtitles for Japanese manga, and that the "words are just more interesting when you read subtitles than when they do the show dubbed in French." Obviously, this justification does not make much sense, since both the subtitles and the dubbed words would be translated from Japanese to French. It seems like his preference could explained in terms of the perception that there is greater prestige associated with subtitled films than with dubbed films. Many of the other informants also recognized the value in watching films with subtitles as opposed to dubbed films:

Adam [age 12]: “These days we are being pushed to watch subtitled movies." Interviewer: "What do you think of that?" Adam [age 12]: "Now, I prefer it because we hear the real voices. The older you 
get, the more you notice that lips aren't matching voices. And then for example, there's a horrible thing, like when I saw Mission Impossible number 5. I saw it in English and then afterward, I saw number 2 in French and it was just horrible, because the voices changed and it didn't seem real."

Violette [age 11]: "I really like Freaky Friday...When I watch movies in English, I watch with subtitles. It doesn't bother me, even though it's true that it's simpler to watch when it's dubbed."

Zoe [age 10]: "When you read the subtitles, you don't see the images. But I prefer subtitles [as opposed to dubbing] if I already know the movie."

Adèle [age 8]: "I really like Japanese manga in movie form. When I watch them on the internet, it's in Japanese, even though it's a little bit of a nuisance because the subtitles are only in English." Interviewer: "Are subtitles a bit of nuisance in general?" Adèle [age 8]: "No, no. My dad loves to watch movies in English, but he always watches them with subtitles. I find it more pleasant to listen to them in English, because it's different from French. I prefer subtitles."

Romane [age 9]: "Sometimes I watch movies with subtitles at the bottom of the screen. But sometimes they go too fast. If I've already seen the movie once in French, it doesn't bother me.”

Yannis [age 11]: "I listen to rap, some American rap and a little more in French." Interviewer: "Does it bother you not to understand the lyrics?" Yannis [age 11]: "No, not at all. I watched Star Wars in English." 
Interviewer: "And the subtitles didn't bother you?"

Yannis [age 11]: “No, not very much, no. My mom watches American TV series with subtitles and I really like to watch them with her."

Though there were clear signs of seeking out cultural products that other children their ages did not know, the informants also demonstrated some social conformity. This is to be expected at their age, since "between uniqueness and conformity, [preadolescents] are in a problematic position, where they must distinguish themselves while still belonging to the group...." (Azam et al. 103).

The degree of social conformity varied across media forms. While adolescents' tastes in television in particular tend to be heavily influenced by peer pressure, for example, when it comes to music, they "have no problem claiming that their practices are eccentric relative to those of their peers" (Pouchadon and Zaffran 177). Interactions with peers also determine the amount of media consumed, and adolescents with low levels of social interaction are twice as likely to be heavy consumers of both recorded music and video games (Octobre 215-216). Another form of social conformity was reflected in a clear distinction between the tastes of boys and of girls. This is hardly surprising, and indeed, several sociological studies conducted in the French context have observed this split, and have shown for example, that "girls on average read more books and magazines than boys, while boys spend more time reading comic books and playing video games" (Peter 132). One of the strongest splits observed with this group of informants was with regard to musical tastes. In fact, every male informant except for two mentioned rap as a favorite genre of music, while none of the female informants chose rap as a favorite style and some of them mentioned explicitly that they do not like it. Camille [age 9] said clearly, "the thing I don't like is rap. Everything that boys listen to is just bad." 
Among the informants were three pairs of siblings and there were signs of conformity in these situations as well, with the younger sibling frequently saying that he or she liked the same things as the older sibling. When Adam [age 12] said, "I love sushi and raclette," Gabriel [age 9], his younger brother, immediately replied, "same for me."

\section{Conclusion}

The informants in this study are learning the ways of Bobos. Though their tastes are not identical to those of their parents, this is likely to be true for the same age group from any social class. They are somewhere in the middle of the process of figuring out what constitutes good taste in their social milieu. It is normal that adult Bobos have acquired more knowledge about what constitutes cultural capital in their world, while the tastes of young children in Bobo families are less filtered by expectations than those of pre-adolescents in this study. These informants might best be described as "proto-Bobos."

Like the tastes of their Bobo parents, these children's tastes reflect the strategies of both the traditional bourgeoisie and of the new cultural omnivores for achieving social distinction. These children's strategies for social distinction resemble the strategies of previous bourgeois generations in several ways. First, children understand that there is value in learning and imitating the tastes of bourgeois parents. Second, these children recognize that cultural capital cannot be easy to acquire or it would lose its value (Samuel's quest for rare manga is an example). Finally, these children understand the value of authenticity in their cultural choices (the appreciation of subtitles is an example). At the same time, these informants show that unlike earlier bourgeois generations, cultural omnivorousness has established itself as a new form of cultural capital. This has manifested itself both through a shift from a hierarchization of foreign 
cultures to hierarchizations within the cultural offerings of each country and through a shift from imagining one genre as superior to another to creating hierarchies of offerings within each genre.

These children's parents already exhibited signs of valuing culturally omnivorous tastes and were the first generation to do so. They in a sense invented it. However, for the children in this study, valuing cultural omnivorousness was more an act of imitation than invention. The fact that an appreciation for cultural omnivorousness has been transmitted from Bobo parents to Bobo pre-adolescents through the traditional bourgeois mechanism of imitation contributes to the legitimacy of this form of cultural capital. It is no longer something new, no longer something that runs counter to the tastes of the previous generation. It is a sign that cultural omnivorousness as a means of social distinction has gone from a probationary, exploratory phase to a more stable and lasting one.

One might wonder why the criteria for what constitutes cultural capital are changing. Increased cultural omnivorousness among young French Bobos is certainly connected to technological changes, increasing ethnic diversity in France, and the globalization of cultural industries. which have all made more cultural options available. This increase in options, however, has not led to a democratization of culture, where equal access to many cultural forms has made it difficult to maintain social distinctions. In fact, it has had the opposite effect. Ever greater resources, in the form of time and cultural knowledge, which are not equally distributed across social groups, are required to sort through the growing number of options and determine which are valuable. Cultural capital must remain rare to maintain its value and this means that knowledge of which cultural products can contribute to it needs to remain a moving target. The enormous amount of options now available to cultural omnivores has only increased the number of possible directions in which that target might move. 
${ }^{1}$ Readers should note that though this article uses the term "popular" to describe mass media forms in television, music, and cinema, the French word "populaire" is used differently, namely to describe something associated with the working-class, and the children in this study never used the term in their discussions with me. The use of the word "populaire" to describe phenomena related to the working class can be traced back at least to 1936, "when such access first became government policy under the Popular Front, it was described as popularisation and indicated by the attachment of the epithet populaire to activities as diverse as theatre, sport and aviation. From then on, for the artists, animateurs and politicians committed to it, la culture populaire tended to signify above all that the working class should have access to cultural, educational and leisure activities previously reserved for a bourgeois elite; it meant a culture brought to people rather than made by them." (David Looseley, "Cultural Democratisation and Popular Music." Modern and Contemporary France, February, 2003, 46-47) In the United States and Britain, “'popular' usually includes mass forms like television and pop music, [while] 'populaire' usually does not. This is conceivably why popular music in the form of rock and pop has always been designated not by the term musique populaire (an expression still not used all that widely, except sometimes in the plural) but by a succession of terms adapted from English: le yéyé, la pop-musique (or just la pop), le rock and more recently la world music, le rap, and la techno..." (Ibid).

${ }^{2}$ For more analysis of Bobos, see (Corbillé; Watrin and Legrand; Gunther).

${ }^{3}$ See for example: Avila-Saavedra, Guillermo, "Neither here nor there: Consumption of US media among pre-adolescent girls in Ecuador," Interactions: Studies in Communication \& Culture, 4: 3 (2013); Huong, Nguyen. "Globalization, Consumerism, And The Emergence Of 
Teens In Contemporary Vietnam," Journal Of Social History 49.1 (2015); Omenugha, Kate Azuka, Chikezie Emmanuel Uzuegbunam, and Ike S. Ndolo, "Celebrity culture, media and the Nigerian youth: negotiating cultural identities in a globalised world." Critical Arts: A SouthNorth Journal of Cultural \& Media Studies 30, no. 2 (2016).

${ }^{4}$ I received approval for this project from Wellesley College's Institutional Review Board, which was required because I was conducting a study with minors. I prepared a consent form (Appendix B), which I had the parents of these children sign. I also asked for verbal assent from each child to make sure that they understood that their participation was completely voluntary, that they could withdraw at any time from the study, and that they could decline to answer any question in the study for any reason.

${ }^{5}$ They cite for example, an early work from Bourdieu (co-authored with Jean-Claude Passeron), Les Héritiers: Les étudiants et la culture, Paris Minuit, 1964.

${ }^{6}$ Peterson provides a summary of these works in (Peterson) He includes work from sociologists around the world: Australia Bennett et al. (1999), Emmison (2003). Austria Gebesmair (1998). Belgium Vander Stichele and Laermans (2003, 2004). Canada Erickson (1996), Fisher and Preece (2003), Friedman and Ollivier (2004). France Hennion et al. (2000), Coulangeon (2003, 2005), Bellevance et al. (2004), Lahire (2004). Germany Kirchberg and Westphal (1997), Hartmann (1999), Gebesmair (2003, 2005). The Netherlands Van Rees et al. (1999), Van Eijck (1999, 2000, 2001), Van Eijck and Bargeman (2004), Van Eijck and Knulst (2005). Israel KatzGerro and Shavit (1998). Spain Lopez-Sintas and Garcia-Alvarez (2002a, 2002b, 2004). Sweden Bihagen and Katz-Garro (2000). United Kingdom Longhurst and Mike (1996), Carrabine and Longhurst (1999), Warde et al. (1999), Olsen et al. (1998), Warde and Martens (2000), Tally Katz-Gerro and Sullivan (2004), Bennett et al. (2005), Savage et al. (2005), Chan and Goldthorp 
(2005). United States Bryson (1996, 1997), DiMaggio (1996), Holt (1997), Kern (1997), Relish

(1997), Roberts (1999), Barnett and Allen (2000), Weiss et al. (2001), Holbrook et al. (2002),

Sonnett (2004), DiMaggio and Mukhtar (2004), Lopez-Sintas and Katz-Gerro (2005). 


\section{Works cited}

Azam, Martine, et al. "La Préadolescence Assistée Par Ordinateur: De La Culture Connectée Aux Tensions Identitaires." Enfance \& Culture: Transmission, Appropriation et Représentation, edited by Sylvie Octobre, La Documentation française, 2015.

Bellavance, Guy, et al. "Le goût des autres : Une analyse des répertoires culturels de nouvelles élites omnivores1." Sociologie et sociétés, vol. 36, no. 1, 2004, pp. 27-57.

Bloomfield, Jude. "'Made in Berlin': Multicultural Conceptual Confusion and Intercultural Reality." International Journal of Cultural Policy, vol. 9, no. 2, July 2003, pp. 167-83. a9h.

Calhoun, Craig. "The Class Consciousness of Frequent Travelers: Toward a Critique of Actually Existing Cosmopolitanism." South Atlantic Quarterly, vol. 101, no. 4, Oct. 2002, pp. 869-97, doi:10.1215/00382876-101-4-869.

Chan, Tak Wing, and John H. Goldthorpe. "Social Stratification and Cultural Consumption: Music in England.” European Sociological Review, vol. 23, no. 1, Feb. 2007, pp. 1-19.

Cicchelli, Vincenzo, and Sylvie Octobre. L'Amateur Cosmopolite: Goûts et Imaginaires Culturels Juvéniles à l'ère de La Globalisation. Ministère de la Culture et de la Communication, Feb. 2017.

Clerval, Anne. Paris sans Le Peuple: La Gentrification de La Capitale. La découverte, 2013.

Corbillé, Sophie. Paris Bourgeoise, Paris Bohème : La Ruée Vers l'Est. Presses Universitaires de France, 2013.

Coulangeon, Philippe. "Social Stratification of Musical Tastes: Questioning the Cultural Legitimacy Model.” Revue Française de Sociologie, vol. Vol. 44, no. 1, pp. 3-34.

Donnat, Olivier. "Les univers culturels des Français." Sociologie et société, vol. 36, no. 1, 2004, pp. 87-103.

Glévarec, Hervé, and Michel Pinet. "Tablatures of Musical Tastes in Contemporary France: Distinction without Intolerance.” Cultural Trends, vol. 21, no. 1, Mar. 2012, pp. 67-88.

Gunther, Scott. "How and Why 'Bobos' Became French.” French Politics, Culture \& Society, vol. 34, no. 3, Dec. 2016, pp. 105-25.

Holt, Douglas. "Does Cultural Capital Structure American Consumption?” The Journal of Consumer Research, vol. 25, no. 1, 1998, pp. 1-25.

Kuisel, Richard. Seducing the French: The Dilemma of Americanization. University of California Press, 1993. 
---. The French Way: How France Embraced and Rejected American Values and Power.

Princeton University Press, 2012.

Looseley, David. "Conceptualising Youth Culture in Postwar France.” Modern \& Contemporary France, vol. 15, no. 3, Aug. 2007, pp. 261-75.

Mandel, Ruth. Cosmopolitan Anxieties: Turkish Challenges to Citizenship and Belonging in Germany. Duke UP, 2008.

Mooij, Marieke de. Global Marketing and Advertising: Understanding Cultural Paradoxes. 2nd edition, SAGE Publications, Inc, 2005.

Octobre, Sylvie. "Les Transmissions Culturelles Chez Les Adolescents: Influences et Stratégies Individuelles." Enfance \& Culture: Transmission, Appropriation et Représentation, edited by Sylvie Octobre, La Documentation française, 2015.

Ollivier, Michèle. "Modes of Openness to Cultural Diversity: Humanist, Populist, Practical, and Indifferent." Poetics, vol. 36, no. 2-3, 2008, pp. 120-47.

Oscherwitz, Dayna L. "Pop Goes the Banlieue: Musical Métissage and the Articulation of a Multiculturalist Vision." Contemporary French \& Francophone Studies, vol. 8, no. 1, Winter 2004, pp. 43-50.

Peter, Christopher. "Petites Princesses Contre Super Héros: Les Médias Destinés Aux 2-14 Ans Mettent-Ils En Scène Le Clivage Des Genres?” Enfance \& Culture: Transmission, Appropriation et Représentation, edited by Sylvie Octobre, La Documentation française, 2015.

Peterson, Richard. "Problems in Comparative Research: The Example of Omnivorousness." Poetics, vol. 33, no. 5-6, 2005, pp. 257-82.

Peterson, Richard, and Robert Kern. "Changing Highbrow Taste: From Snob to Omnivore." American Sociological Review, vol. 61, no. 5, 1996, pp. 900-07.

Pouchadon, Marie-Laure, and Joël Zaffran. "La Recomposition Des Pratiques Culturelles Des Adolescent(e)s: Terrain Français, Éclairages Québécois." Enfance \& Culture: Transmission, Appropriation et Représentation, edited by Sylvie Octobre, La Documentation française, 2015.

Watrin, Laure, and Thomas Legrand. La République Bobo. Stock, 2014. 


\section{Appendix A}

\section{List of informants}

\begin{tabular}{|l|c|c|}
\hline Pseudonym & Age & Sex \\
\hline Manon & 7 & $\mathrm{f}$ \\
\hline Noah & 7 & $\mathrm{~m}$ \\
\hline Sasha & 7 & $\mathrm{~m}$ \\
\hline Adèle & 8 & $\mathrm{f}$ \\
\hline Louis & 8 & $\mathrm{~m}$ \\
\hline Mathis & 8 & $\mathrm{~m}$ \\
\hline Camille & 9 & $\mathrm{f}$ \\
\hline Clément & 9 & $\mathrm{~m}$ \\
\hline Damien & 9 & $\mathrm{~m}$ \\
\hline Gabriel & 9 & $\mathrm{~m}$ \\
\hline Jennie & 9 & $\mathrm{f}$ \\
\hline Quentin & 9 & $\mathrm{~m}$ \\
\hline Romane & 9 & $\mathrm{f}$ \\
\hline Théo & 9 & $\mathrm{~m}$ \\
\hline Virgil & 12 & $\mathrm{~m}$ \\
\hline Chloé & 10 & $\mathrm{f}$ \\
\hline Eugénie & 10 & $\mathrm{f}$ \\
\hline Jane & 10 & $\mathrm{f}$ \\
\hline Maxime & 10 & $\mathrm{~m}$ \\
\hline Samuel & 10 \\
\hline Zoe & 10 \\
\hline Violette & $\mathrm{f}$ \\
\hline Yannis & 10 \\
\hline Adam & 10 & \\
\hline Alma & 9 & $\mathrm{f}$ \\
\hline
\end{tabular}


Appendix B

Formulaire de Consentement : La consommation médiatique des pré-adolescents en

France

Je sousigné(e), , autorise mon(mes)

enfant(s), , à

participer à l'enquête « la consommation médiatique des pré-adolescents en France » menée par Scott Gunther de Wellesley College. Je comprends qu'il s'agit d'étudier les attitudes des préadolescents français vis-à-vis de diverses options médiatiques afin de comprendre à quel point leurs attitudes des médias populaires étrangers ressemblent ou diffèrent des opinions des préadolescents déjà étudiés dans d'autres pays.

Je comprends que mon(mes) enfant(s) se réunira/réuniront avec le chercheur et d'autres enfants (jusqu'à 5 enfants total) entre 7 et 12 ans pendant une heure maximum. Le chercheur posera aux participants des questions générales sur leurs préférences médiatiques et fera un enregistrement audio de la conversation.

Je comprends que mon(mes) enfant(s) ne recevra/recevront pas de bénéfice direct pour sa/leur participation dans l'étude, mais contribuera/contribueront à l'érudition académique dans le domaine des études sociologiques des comportements médiatiques des enfants.

Je comprends que la participation de mon(mes) enfant(s) est entièrement volontaire et qu'il(s)/elle(s) peut/peuvent se retirer à n'importe quel moment de cette étude, que ce soit avant les conversations en groupe ou pendant, et peut/peuvent refuser de répondre aux questions posées pour n'importe quelle raison. Avant de commencer la conversation, le chercheur vérifiera oralement avec les enfants qu'ils comprennent qu'ils peuvent se retirer de l'étude, qu'ils peuvent 
refuser de répondre aux questions, et que tout ce qu'ils disent restera confidentiel (le cas échéant, il expliquera le sens du mot « confidentiel »).

Je comprends que toute information qui pourrait servir à identifier mon(mes) enfant(s) restera confidentielle et ne figurera pas dans l'article final. Le chercheur gardera les enregistrements audio et ne les partagera avec personne. J'ai lu et compris ce formulaire de consentement et permets à mon(mes) enfant(s) de participer à cette enquête. Le chercheur me fournira une copie de ce formulaire que je pourrai garder.

Signature du parent :

Date :

Signature du chercheur :

Date :

Nom(s) et date(s) de naissance de l'enfant/des enfants :

Nom et l'adresse email du parent :

Nom et l'adresse email du chercheur : [author's name and email address]

Pour les questions concernant l'expérience de votre enfant pendant l'enquête, veuillez contacter : le chef du comité de déontologie [contact information for IRB at author's institution]

Une copie de ce formulaire est aussi valable que l'original. 